\title{
Reduced aggression and foraging efficiency of invasive signal crayfish (Pacifastacus leniusculus) infested with non-native branchiobdellidans (Annelida: Clitellata)
}

\author{
J. James ${ }^{1 *}$, K. E. Davidson ${ }^{1}$, G. Richardson ${ }^{1}$, C. Grimstead ${ }^{2}$ and J. Cable ${ }^{1}$
}

\begin{abstract}
Background: Biological invasions are a principal threat to global biodiversity and identifying the determinants of non-native species' success is a conservation priority. Through their ability to regulate host populations, parasites are increasingly considered as important in determining the outcome of species' invasions. Here, we present novel evidence that the common crayfish ecto-symbiont, Xironogiton victoriensis (Annelida: Clitellata) can affect the behaviour of a widespread and ecologically important invader, the signal crayfish (Pacifastacus leniusculus).

Methods: To assess the signal crayfish-X. victoriensis relationship naïve crayfish were infested with an intensity of worms typically observed under natural conditions. Over a 10-week period the growth rate and survivorship of these animals was monitored and compared to those of uninfested counterparts. Complementary dyadic competition and foraging experiments were run to assess the behaviour of infested compared to uninfested animals. These data were analysed using General Linear Models and Generalized Linear Mixed Models.
\end{abstract}

Results: Whilst $X$. victoriensis did not affect the growth rate or survivorship of signal crayfish under laboratory conditions, infested animals were significantly less aggressive and poorer foragers than uninfested individuals. Conclusions: Through reducing aggression and foraging efficiency, infestation with $X$. victoriensis may disrupt the social structure, and potentially growth rate and/or dispersal of afflicted crayfish populations, with potential effects on their invasion dynamics. This is important given the widespread invasive range of crayfish and their functional roles as ecosystem engineers and keystone species.

Keywords: Freshwater invasions, Crustacean parasites, Intraspecific competition, Co-introduced symbionts, Xironogiton victoriensis

\section{Background}

Biological invasions are a principal threat to global biodiversity [1], and freshwater ecosystems are particularly vulnerable to the effects of invasive species [2]. These threats are likely to intensify with the predicted increase in future invasion rates $[3,4]$. Of all introduced species, around $1 \%$ will ultimately become invasive $[5,6]$, and identifying the determinants of this is a conservation priority. Parasites, or the lack thereof, can alter host invasion dynamics [7-9] and in some cases are considered

\footnotetext{
* Correspondence: jamesj12@cardiff.ac.uk

'School of Biosciences, Cardiff University, Cardiff CF10 3AX, UK

Full list of author information is available at the end of the article
}

to be the key factor determining the outcome of species' invasions [10].

Most often the role of parasites in determining invasion success is considered in the context of the Enemy Release Hypothesis which postulates that escape from natural enemies facilitates the establishment and spread of non-native species [11]. In their non-native range, introduced animals can escape over $75 \%$ of their native parasites [7], only about $25 \%$ of which are replaced by parasites acquired from the recipient ecosystem [12]. It is unsurprising, therefore, that the role of many parasites (co-introduced or acquired from their new habitat) in controlling invaders is comparatively 
understudied [13, 14]. The effects of parasites on non-native hosts may be equally as profound as those resulting from parasite absence. For instance populations of invasive rusty crayfish (Orconectes rusticus) in North America exist in alternate abundance states that can be at least partially explained by the presence of a trematode parasite, Microphallus sp., which reduces crayfish abundance and population growth [14].

Identifying factors that allow non-natives to thrive in new environments is particularly important for crustaceans, which comprise a disproportionately large proportion of the 13 freshwater species listed among the 100 'worst' invasive species [15]. In particular crayfish have been widely translocated for aquaculture $[15,16]$, and their invasive range now extends throughout most of Europe [17, 18] and into Asia [19]. Invasive crayfish pose a significant threat to freshwater biodiversity and ecosystem functioning $[20,21]$. They are host to a wide range of fungi, viruses, bacteria, protists and metazoans [22], many of which may alter their invasion success if cointroduced. It is well established that the spread of North American crayfish across Europe is facilitated by transmission of Aphanomyces astaci, the causative agent of crayfish plague, to susceptible European crayfish, in which infection is typically lethal [23-26]. In contrast, North American crayfish species are largely resistant to the disease [23] and therefore gain a competitive advantage over native crayfish species.

Whilst $A$. astaci has been extensively reported, other lesser-known groups of symbionts may also affect crayfish invasion dynamics. One such group are the branchiobdellidans, ecto-symbiotic annelids that have a widespread global distribution across the Nearctic and two disjunct regions of the Palearctic [27]. Invasive American branchiobdellidans were first recorded in Europe on North American signal crayfish (Pacifastacus leniusculus) from Sweden during the 1960s [28] and have since been found in Austria [29], Finland [30], Spain [27, 31, 32], Italy [33, 34], France [29, 35, 36], Hungary [37], and most recently from the UK [38]. The impact of branchiobdellidans on the invasion dynamics of crayfish in these countries is however difficult to predict given the variable nature of the crayfishbranchiobdellidan relationship [39]. Although branchiobdellidans are generally considered commensals [40-42], their association with crayfish can vary from mutualism [43-45] to parasitism [44, 46, 47] depending on the host, branchiobdellidan species and density, and environmental conditions. Also, many species of branchiobdellidans have been categorized as commensals based only on crayfish growth rate and/or survivorship studies (e.g., [41]), although it is known that ectosymbionts alter host behaviour in multiple ways, some of which reduce host fitness (e.g., [48]). Therefore whilst branchiobdellidans clearly have the potential to influence the invasion dynamics of non-native crayfish; elucidating the nature of this effect is complex.

Here, in a series of laboratory experiments, we assessed the impact of Xironogiton victoriensis (Annelida: Clitellata) on the growth rate, survivorship and behaviour of their native signal crayfish hosts [49]. Our aim was to investigate how these symbionts may influence the invasion dynamics of signal crayfish in their non-native range.

\section{Methods}

\section{Collection and husbandry of experimental animals}

In June 2013, Xironogiton victoriensis infested signal crayfish were collected from the River Gavenny (Abergavenny, Wales) and uninfested crayfish from the Bachowey River (Powys, Wales). All crayfish were harvested using standardised manual searches (stone turning and kick sampling). Following capture, animals from each population were transported to Cardiff University and housed in separate $100 \mathrm{~L}$ tanks filled with dechlorinated water $\left(15 \pm 1{ }^{\circ} \mathrm{C}\right)$ under a $16 \mathrm{~h}: 8 \mathrm{~h}$ light/dark regime, at a density of ca. 15 individuals $/ \mathrm{m}^{2}$. All experiments were conducted under these environmental conditions, and using only crayfish from the uninfested population. Stock tanks were supplied with gravel substrate $(2 \mathrm{~cm})$ and sufficient refuges (plastic tubes and plant pots) for all animals. Crayfish were fed daily with Tetra Crusta crayfish food pellets and $50 \%$ water changes were performed weekly. Crayfish with regenerating or missing chela or displaying signs of disease were not used in any experiment. Upon termination of experiments, all animals were humanely destroyed by freezing at $-20{ }^{\circ} \mathrm{C}$, in accordance with the Wildlife and Countryside Act, 1981.

For use in foraging efficiency trials, Gammarus pulex were collected from the same location as the uninfested crayfish, Bachowey River (Powys, Wales), in May 2014 using a fine-mesh dip net. These gammarids were maintained in a $60 \mathrm{~L}$ tank filled with dechlorinated water and housed under the same temperature and lighting conditions as the experimental crayfish. Gammarids were fed daily with a mixture of Spirulina, yeast and dechlorinated water.

\section{Experimental infestations with branchiobdellidans}

Worms carefully dislodged from naturally infested signal crayfish using the edge of blunt forceps into a Petri dish, were checked that they remained active and undamaged using a dissecting microscope with fibre optic illumination. Worms in good condition were then transferred on to the carapace of recipient animals using forceps, and observed to ensure that they had fully attached to 
the recipient crayfish. Experimental infestation loads were based on those in a naturally infested wild population of signal crayfish, which varied according to host size ([38] and see below).

\section{The effect of branchiobdellidan infestation on signal crayfish growth and behaviour}

To investigate the effects of long term exposure to branchiobdellidans on crayfish growth, individually maintained animals were weighed weekly over a 10 week period ( $n=40$ per treatment, sex and size matched to within $10 \%$ carapace length, CL), and then interactions between infested vs uninfested individuals were assessed over one day. Crayfish were housed in $15 \mathrm{~L}$ tanks containing a single plant pot refuge and fed every $48 \mathrm{~h}$ with $2 \mathrm{~g}$ of commercial fish food flakes. Crayfish in the infested treatment were grouped in the following size categories (CL, mm): $28-31 ; 32-35$; 36-39; 40-43; 4448 , and infected with $21,28,65,101$ and 154 worms respectively, these reflect natural burdens of $X$. victoriensis on signal crayfish [38]. Weekly, infested crayfish were screened and, if their branchiobdellidan burden declined at any point, new worms were added to maintain a constant infection intensity on each crayfish throughout the experiment. Branchiobdellidan declines were expected as crayfish commonly regulate worm densities through grooming [50], a behaviour frequently observed during our experiments. If a crayfish moulted, the moult was left in the tank for at least $24 \mathrm{~h}$ to allow worms to transfer back onto the crayfish.

At the end of the 10 week experiment, dyadic competition trials were conducted between infested and uninfested crayfish in an experimental tank (L60 cm x W30 $\mathrm{cm} \times \mathrm{D} 30 \mathrm{~cm}$ ) separated into three compartments using a mobilised plastic divider. Prior to trials commencing, an infested crayfish, and a sex and size matched (within $10 \%$ carapace length) uninfested crayfish, were placed on either side of the divider. After 5 min acclimatisation the mobile dividers were lifted and interactions between the infested and uninfested crayfish recorded for $1 \mathrm{~h}$ using Micropix USB webcam cameras. The number of intraspecific interactions made by each crayfish during the trial period was subsequently recorded. It was not possible to distinguish which crayfish were infested in these webcam recordings, thus all observations were made "blind" using an identifying nail polish mark applied to the dorsal carapace to recognise individuals. The four types of intraspecific behaviours recorded were characterised as: i) fight - whereby a physical interaction is initiated (chelae strike/locking), ii) threat - where one crayfish approaches another in a threatening posture (e.g., chelae raised) but no physical contact is made, iii) retreat - where a crayfish retreats from a physical interaction (i.e., backs down from a fight) and, iv) avoid - when a crayfish moves away from an approaching crayfish but no physical interactions have taken place (i.e., the crayfish moves away from a threatening opponent). For these competition experiments, we recorded the number of worms on the infested and uninfested crayfish at the start and end of the trial respectively and the total contact duration(s) between the pair over the $1 \mathrm{~h}$ test period.

\section{The effect of branchiobdellidan infestation on crayfish foraging efficiency}

To determine whether short-term exposure of naïve signal crayfish to branchiobdellidans altered their foraging efficiency we experimentally infested signal crayfish $(n=$ $25)$ with $X$. victoriensis and assessed their predation on gammarids, compared to uninfested controls $(n=25)$. Crayfish were housed individually in $10 \mathrm{~L}$ tanks, containing a single plant pot refuge, and allowed to acclimatise for three days. On Day 3 half of the crayfish were infected with branchiobdellidans and the other half sham infected by handling alone without exposure to $X$. victoriensis. Infested crayfish received 90 worms, reflecting the mean natural infection intensity for crayfish of the size used in the experiment, 38.6-62.1 $\mathrm{mm}$ carapace length [38]. Following experimental infection, each crayfish was returned to its respective $10 \mathrm{~L}$ tank and left to acclimatise, without being fed, for 3 days prior to foraging experiments commencing. On Day 6, the refuge was removed from all tanks and five live gammarids (size range: $6-12 \mathrm{~mm}$ body length) were introduced. Latency to attack (time taken to launch the first attack, irrespective of success) and the number of gammarids each crayfish consumed was recorded at 10, 30, $60 \mathrm{~min}$ and $18 \mathrm{~h}$. At the end of the experiment, the number of worms remaining on each crayfish was also recorded.

\section{Statistical analysis}

All analyses were conducted in the $\mathrm{R}$ statistical package v2.15.1 [51] with Generalized Linear Mixed Models (GLMMs) being conducted using the ASReml-R (version 3.0 package within the $\mathrm{R}$ interface). For each model the error distribution (quasi-poisson, gaussian, poisson or Gamma) was selected by; visualizing histograms of the dependent variable, assessing residual plots as recommended by Pinheiro and Bates [52] and, specifically for quasi-poisson models, measuring over-dispersion using the dispersion parameter, theta [53]. Non-significant terms were sequentially deleted from starting models using Analysis of Variance for General(ised) Linear Models [54] and the Wald statistic for GLMMs [53], and only significant terms are reported. The fit of the refined models, was assessed using residual plots [52].

A General Linear Model with a gaussian error distribution and identity link function was used to assess 
whether the percentage change in weight of crayfish over the experiment was significantly different between infested $(n=36)$ and uninfested crayfish $(n=26$ at the end of the experiment). Crayfish size (carapace length, CL $\mathrm{mm}$ ), sex and whether or not the crayfish moulted during the experiment were included as independent variables, as well as interaction terms between infestation status and both crayfish size and moult status. A Chi square test was used to compare the number of crayfish moults in the infected $(n=36)$ and uninfested group $(n=26)$.

Generalised Linear Models with a quasi-poisson error distribution and log link function were used to assess the effect of crayfish infestation status (branchiobdellidan infested or control), sex and size (CL $\mathrm{mm}$ ) on their behaviour. Data for each behaviour type (i.e., fight, threat, retreat, avoid) were analysed independently and models also included the total number of all behaviours performed by each crayfish as a controlling variable.

For crayfish in the infested treatment group $(n=28)$ quasi-poisson Generalised Linear Models (log link function) were run to assess the impact of infestation intensity (measured as the number of worms on the infested crayfish at the start of the trial) on crayfish behaviour. As infestation intensity and crayfish size (CL) were positively correlated (Pearson's correlation: $t=6.02, d f=26$, $P<0.001)$ analysing them as separate independent variables could cause issues relating to collinearity (see [53]). Therefore, for each behaviour, we ran three separate GLMs; one including crayfish size (CL) and infestation intensity as independent variables, one just including crayfish size (CL), and another just including infestation intensity. All models also included as independent variables, crayfish sex and the total number of all behaviours performed by each crayfish. All behaviour types were analysed individually. A separate Generalised Linear Model with a Gamma error distribution and a log link function was used to assess how crayfish infestation intensity (i.e., the number of worms on the infested crayfish at the start of the trial) is influenced by sex and size (CL mm).

A Kendall-Tau correlation was used to determine if the number of worms transmitted to the originally uninfested crayfish was correlated to the number of worms on the infested crayfish at the start of the trial. We also used a Kendall-Tau correlation to test whether the proportion of worms on the infested crayfish that were transmitted to the originally uninfested animal over the $1 \mathrm{~h}$ trial period was correlated with their total contact duration(s).

A General Linear Model with a gaussian error distribution and identity link function was used to investigate the effect of infestation status (control, $n=25$, or infected, $n=25$ ), crayfish size (carapace length) and crayfish sex on the (log transformed) latency to attack gammarid prey. A GLMM with a gaussian error structure and identity link function was used to investigate the effect of infestation status, crayfish size and crayfish sex on the number of gammarids captured over the duration of the experiment. For crayfish in the infested treatment group $(n=25)$, GLMMs (gaussian family, identity link) were performed to assess the effect of infestation intensity (at the end of the trial) on the number of gammarids captured. For this, three separate GLMMs were run because of the collinearity between crayfish size and infestation intensity (Pearson's correlation: $t=$ 2.55, $d f=23, P=0.02)$; one including infestation intensity, crayfish size and crayfish sex as independent variables, the second including just infestation intensity and sex, and the third including just crayfish size and sex. To control for repeated measures, both crayfish identification number and time of record (10, 30, $60 \mathrm{~min}$ or $18 \mathrm{~h}$ ) were included as random effects in all GLMMs. Interactions between all independent variables were included in each initial model.

\section{Results}

\section{The effect of branchiobdellidan infestation on signal} crayfish growth and behaviour

Over the 10 week experiment, there was no significant difference in the percentage weight change (GLM: $P>0.05)$ or number of moults $\left(\mathrm{X}^{2}=0.008, d f\right.$ $=1, P=0.98)$ between uninfested and infested signal crayfish. Smaller crayfish and those that moulted gained more weight than larger crayfish or those that did not moult (GLM: $F_{1,63}=97.38, P<0.0001, F_{1,63}=$ $16.78, P<0.001$ respectively). There was no apparent difference in growth between male and female crayfish $(P>0.05)$.

During dyadic interactions, infested crayfish performed significantly less fight (GLM: Deviance ${ }_{1}, 53=$ 313.42, $P<0.0001$ ) and threat $\left(\right.$ Deviance $_{1,53}=405.46$, $P=0.02$ ) behaviours, and significantly more retreat (Deviance $_{1}, 53=349.35, P<0.0001$ ) and avoid (Deviance $_{1,53}=445.90, P<0.01$ ) behaviours than uninfested crayfish (Fig. 1). No effects of sex or size on crayfish behaviour were detected $(P>0.05$ for all).

For infested crayfish the number of avoid behaviours performed by females was significantly higher than that of male crayfish $(P<0.05)$ for all three models (i.e., including crayfish size and infestation intensity as variables together and singularly, Table 1). Males performed more threat behaviours than female crayfish (GLM: Deviance $_{1,25}=200.31, P=0.05$ ) but this effect was only significant when not controlling for infestation intensity (Table 1). (GLM: $\mathrm{LRT}_{1,25}=6.31, P=0.01 ; \mathrm{LRT}_{1,25}=4.70$, $P=0.03$, respectively). Infestation intensity was negatively correlated with the number of crayfish avoid 


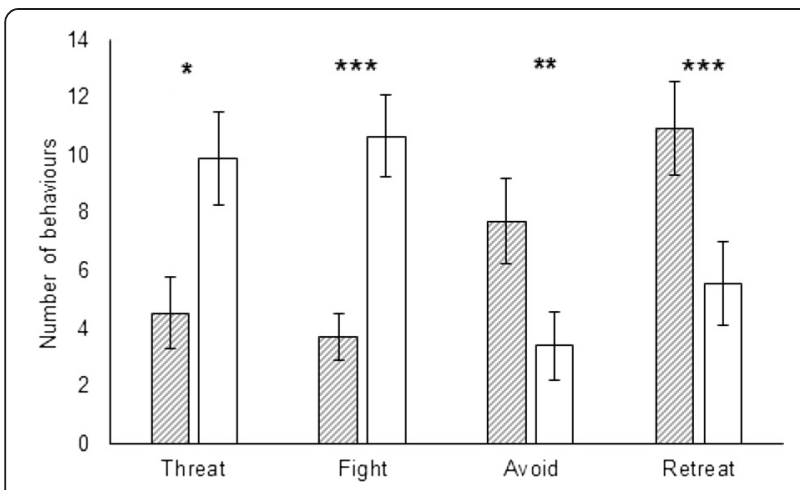

Fig. 1 Effect of branchiobdellidan infestation on host aggressive behaviour. Mean $( \pm S E)$ number of threat, fight, avoid and retreat behaviours performed by Xironogiton victoriensis infested (hatched bars) and uninfested (white bars) signal crayfish in dyadic competition experiments. ${ }^{*} P<0.05$, ${ }^{*} P<0.01,{ }^{* * *} P<0.0001$

behaviours ( Deviance $_{1,24}=116.20, \quad P=0.05$ ), although this was only significant when not controlling for crayfish size (CL) (Table 1). Infestation intensity was positively correlated with the number of threat behaviours initiated by crayfish $(P<0.01)$ when infestation intensity was included in the two models with and without crayfish size as a variable (Table 1). The number of worms on infested crayfish at the start of the trial was positively correlated with crayfish size (GLM: $F_{1,25}=77.98, P<$ $0.001)$ and higher for male than female crayfish $\left(F_{1,25}=\right.$ 18.30, $P<0.001$ ).

In behavioural trials at least one worm was successfully transmitted to $89.3 \%$ of the originally uninfested hosts within one hour. The total number of worms transmitted to the uninfested animal was positively correlated to the number of worms on the infested individual at the start of the trial (Kendall-Tau correlation test: $z=4.09, P<0.001$ ) (Fig. 2). There was, however, no significant correlation between the proportion of worms on the infested crayfish that were transmitted to the originally uninfested animal and their total contact duration (Kendall-Tau correlation: $z=1.36, P=0.17$ ).

\section{The effect of branchiobdellidan infestation on crayfish foraging efficiency}

Infested crayfish captured fewer gammarids than uninfested crayfish at each time point, and this difference was significant overall $\left(F_{1,197}=12.76, P<0.001\right.$; Fig. 3$)$, although there was no difference in the latency to attack between these control and treatment groups $(P>0.05)$. Within the infested group $(n=25)$, crayfish with a higher infestation intensity captured fewer gammarids (Table 2). Infestation with Xironogiton victoriensis is predicted to reduce prey consumption by $19.6 \%$ for female and

Table 1 The structure of Generalized Linear Models used to investigate the effects of sex, size (carapace length, CL mm) and infestation intensity on the number of avoiding, retreating, threatening and fighting behaviours performed by Xironogiton victoriensis (Annelida: Clitellata) infested signal crayfish (Pacifastacus leniusculus)

\begin{tabular}{|c|c|c|c|c|c|}
\hline Dependent variable & Independent variables & Significant terms & Deviance & Df & $P$ \\
\hline \multirow[t]{9}{*}{ No. of avoid behaviours } & \multirow[t]{3}{*}{ Sex, Size (CL mm), Infestation Intensity, Total Behaviours } & Sex & 129.54 & 1,24 & $<0.01$ \\
\hline & & Size (CL mm) & 116.20 & 1,24 & 0.03 \\
\hline & & Total Behaviours & 212.15 & 1,24 & $<0.0001$ \\
\hline & \multirow[t]{3}{*}{ Sex, Size (CL mm), Total Behaviours } & Sex & 129.54 & 1,24 & $<0.01$ \\
\hline & & Size (CL mm) & 116.20 & 1,24 & 0.03 \\
\hline & & Total Behaviours & 212.15 & 1,24 & $<0.0001$ \\
\hline & \multirow[t]{3}{*}{ Sex, Infestation Intensity, Total Behaviours } & Sex & 119.80 & 1,24 & 0.03 \\
\hline & & Infestation Intensity & 116.20 & 1,24 & 0.05 \\
\hline & & Total Behaviours & 195.88 & 1,24 & $<0.0001$ \\
\hline \multirow[t]{3}{*}{ No. of retreat behaviours } & Sex, Size (CL mm), Infestation Intensity, Total Behaviours & Total Behaviours & 219.89 & 1,26 & $<0.0001$ \\
\hline & Sex, Size (CL mm), Total Behaviours & Total Behaviours & 219.89 & 1,26 & $<0.0001$ \\
\hline & Sex, Infestation Intensity, Total Behaviours & Total Behaviours & 219.89 & 1,26 & $<0.0001$ \\
\hline \multirow[t]{3}{*}{ No. of threat behaviours } & Sex, Size (CL mm), Infestation Intensity, Total Behaviours & Infestation Intensity & 200.31 & 1,25 & $<0.01$ \\
\hline & Sex, Size (CL mm), Total Behaviours & Sex & 200.31 & 1,25 & 0.05 \\
\hline & Sex, Infestation Intensity, Total Behaviours & Infestation Intensity & 200.31 & 1,25 & $<0.01$ \\
\hline \multirow[t]{3}{*}{ No. of fight behaviours } & Sex, Size (CL mm), Infestation Intensity, Total Behaviours & Nothing & N/A & $\mathrm{N} / \mathrm{A}$ & N/A \\
\hline & Sex, Size (CL mm), Total Behaviours & Nothing & N/A & $\mathrm{N} / \mathrm{A}$ & N/A \\
\hline & Sex, Infestation Intensity, Total Behaviours & Nothing & N/A & $\mathrm{N} / \mathrm{A}$ & N/A \\
\hline
\end{tabular}

For significant terms $(P \leq 0.05)$ the deviance, degrees of freedom (df) and $P$-values are reported. In each model, the total number of all types of behaviours performed by crayfish was also included as a controlling variable, which was retained in the final refined models (after stepwise deletions of non-significant terms based on Analysis of Variance) even if not significant 


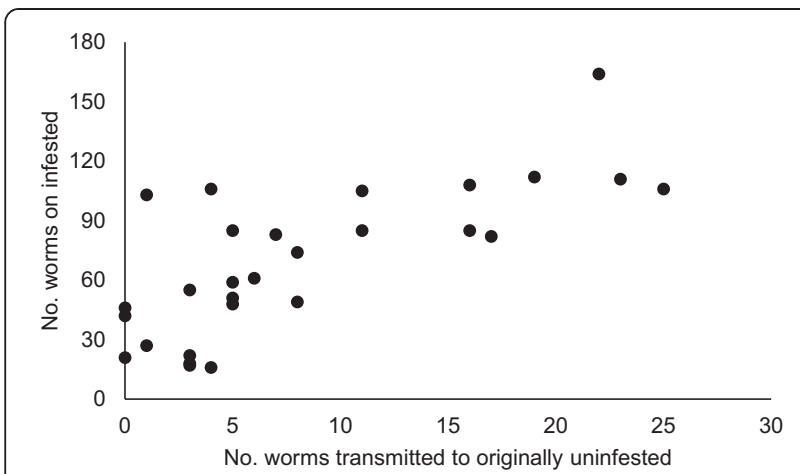

Fig. 2 Correlation between host branchiobdellidan infestation intensity and transmission potential. Number of branchiobdellidans on the infested crayfish in relation to the number of worms transmitted to the originally uninfested animal during dyadic competition experiments

$22.6 \%$ for male crayfish (GLMM). Irrespective of infestation status male crayfish consumed fewer gammarids than female crayfish, with crayfish sex a significant term in both the infestation status $\left(F_{1}, 197=5.80, P=0.017\right)$ and infestation intensity (Table 2) models (Fig. 3).

\section{Discussion}

Here, we find that whilst the branchiobdellidan Xironogiton victoriensis did not affect the growth rate of invasive signal crayfish (Pacifastacus leniusculus), infested animals were less aggressive and less efficient foragers than their uninfested counterparts. These behavioural effects may reduce the overall fitness of infested crayfish, in which case $X$. victoriensis would be considered parasitic on signal crayfish. Field studies are, however, needed to assess if the observed behavioural changes of $X$. victoriensis-infested signal crayfish translate into fitness costs in the wild. Regardless, the current study demonstrates that branchiobdellidans can alter host behaviour in multiple ways, thus determining the nature of crayfishbranchiobdellidan relationships is not straightforward.

Branchiobdellidans have variable effects on crayfish growth depending on worm species, density and environmental conditions [41, 43-45]. Gill frequenting branchiobdellidans, such as Branchiobdella kobayoshi and some Cambarincola species', clean epibionts from the branchial chambers promoting host respiration and growth [43-45]. This cleaning behaviour may, however, only be beneficial towards crayfish under conditions of high environmental fouling pressure [45]. Indeed, when worm densities exceed epibiont availability, branchiobdellidans may switch to a diet of host gill tissue [44]. There is some evidence that high densities of gill frequenting branchiobdellidans may reduce host growth rate [44]. As X. victoriensis is not known to occupy crayfish gill chambers it is perhaps unsurprising that we did not detect any effects of infestation on host growth rate. A study using Cambarincola fallax, which primarily inhabits the subrostral region of the crayfish exoskeleton [55], also failed to detect any effects of infestation on host growth rate [41].

The effect of branchiobdellidans on the agonistic behaviour of their crayfish hosts has, to our knowledge, never previously been assessed. Overall, we found that branchiobdellidan infested crayfish exhibited lower aggression levels than their uninfested counterparts, which is predicted to be costly in terms of fitness, given the naturally aggressive nature of these animals [56]. The poorer performance of infested animals during agnostic interactions suggests that branchiobdellidan infestation may reduce the host's ability to access resources such as food, shelter and reproductive partners. The effects of branchiobdellidans on crayfish behaviour may be sex dependant with more pronounced effects noted for females. Regardless, branchiobdellidans do affect crayfish

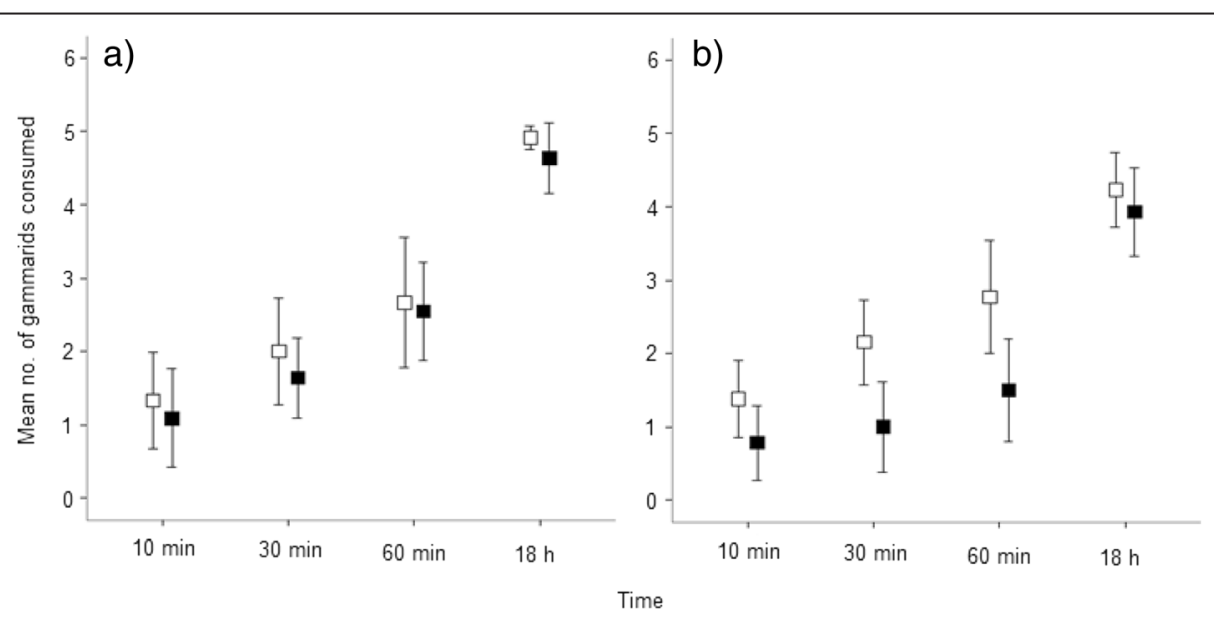

Fig. 3 Effect of branchiobdellidan infestation on host foraging efficiency. Mean number of gammarids consumed ( $\pm 95 \%$ Cl) by uninfested (unfilled boxes) and Xironogiton victoriensis infested (filled boxes) female (a) and male (b) signal crayfish after 10, 30, 60 min and $18 \mathrm{~h}$ 
Table 2 The structure of Generalized Linear Mixed Models used to investigate the effects of sex, size (carapace length, CL mm) and infestation intensity on the number of gammarids consumed by Xironogiton victoriensis (Annelida: Clitellata) infested signal crayfish (Pacifastacus leniusculus)

\begin{tabular}{|c|c|c|c|c|c|}
\hline Fixed terms & Random terms & Significant fixed terms & $\mathrm{F}$ (incremental) & Df & $P$ \\
\hline \multirow{2}{*}{$\begin{array}{l}\text { Sex, Size (CL mm), Infestation Intensity, Size: Sex, Sex: } \\
\text { Infestation Intensity, Size: Infestation Intensity }\end{array}$} & \multirow[t]{2}{*}{ Time in experiment, Crayfish ID. } & Sex & 4.84 & 1,94 & $<0.01$ \\
\hline & & Infestation Intensity & 15.83 & 1,94 & 0.03 \\
\hline Sex, Size (CL mm), Size: Sex & Time in experiment, Crayfish ID. & Sex & 9.38 & 1,95 & $<0.01$ \\
\hline \multirow[t]{2}{*}{ Infestation Intensity, Sex, Sex: Infestation Intensity } & \multirow[t]{2}{*}{ Time in experiment, Crayfish ID. } & Sex & 10.30 & 1,94 & 0.03 \\
\hline & & Infestation Intensity & 10.36 & 1,94 & $<0.01$ \\
\hline
\end{tabular}

For significant terms $(P \leq 0.05)$ the F-statistic, degrees of freedom (df) and $P$-values are reported

aggressiveness, which may alter development of dominance hierarchies, with potential consequences for host population dynamics.

As branchiobdellidans have a direct life cycle and are transmitted during host-host contact [57], reduced host aggression may result in decreased worm transmission rates. We, however found no evidence that the proportion of branchiobdellidans transmitted was correlated with the duration of contact between the infested and uninfested crayfish. Conversely, there was a significant positive correlation between infestation intensity (i.e., the number of worms on the infested crayfish at the start of the trial) and the proportion of worms transmitted to the originally uninfested host. Branchiobdellidan intensity may therefore be a better predictor of transmission rate than duration of host-host contact, although presumably both factors are crucial for worm transmission in wild populations.

In terms of foraging efficiency infested animals captured, on average, fewer prey items than their uninfested counterparts. Among infested crayfish, infestation intensity was negatively correlated with the number of prey caught. By decreasing foraging efficiency branchiobdellidans may reduce long term growth in the wild where prey is limited and more spatially distributed. This may carry high fitness costs for crayfish where size is correlated to dominance [56] and reproductive success $[58,59]$. Further studies are needed to elucidate whether $X$. victoriensis infestation is detrimental to crayfish fitness under natural conditions. Such studies are vital if we are to predict the effects of $X$. victoriensis infestation on signal crayfish invasion.

\section{Conclusions}

This is first report of branchiobdellidans affecting host behaviour, in this case competitive interactions and foraging of crayfish. The mechanism driving these behavioural changes is unclear, but we hypothesize that it may be driven by branchiobdellidans stimulating mechanoreceptors on the crayfish exoskeleton, and thus causing interference with other behaviours (e.g., foraging and intraspecific interactions). A similar mechanism was recently proposed as being the cause of reduced foraging aptitude and predator detection in flea infested gerbilline rodents [48]. Regardless of the causal mechanism, these behavioural changes are likely to disrupt the social structure, and potentially growth rate and/or dispersal of branchiobdellidan infested signal crayfish populations in the wild. As crayfish are keystone species that interact with organisms on multiple trophic levels and alter nutrient cycling processes [21] such changes to signal crayfish population dynamics, as well as to individual animal behaviour, may have important ecosystem level consequences. This is particularly salient considering the widespread invasive range of these crayfish [16-19].

\section{Competing interests}

The authors declare that they have no competing interests.

\section{Authors' contributions}

JJ and JC designed the study. JJ, GR and KED conducted field and laboratory work. JJ and KED performed the statistical analyses and wrote the manuscript. JC and CG provided feedback on drafts of the manuscript. All authors read and approved the final manuscript.

\section{Acknowledgements}

We thank Clare Baranowski for laboratory assistance. KED was part-funded by the Morgan E Williams Helminthology Scholarship at Cardiff University.

\section{Author details}

${ }^{1}$ School of Biosciences, Cardiff University, Cardiff CF10 3AX, UK. ${ }^{2}$ Natural Resources Wales, Rivers House, St. Mellons, Cardiff CF3 OEY, UK.

Received: 5 August 2015 Accepted: 6 November 2015

Published online: 17 November 2015

\section{References}

1. Wilcove DS, Rothstein D, Dubow J, Phillips A, Losos E. Threats to imperiled species in the United States. Bio Sci. 1998:48:607-15.

2. Dudgeon D, Arthington AH, Gessner MO, Kawabata Z, Knowler DJ, Lévêque $C$, et al. Freshwater biodiversity: importance, threats, status and conservation challenges. Biol Rev. 2006;81:163-82.

3. Ricciardi A. Facilitative interactions among aquatic invaders: is an "invasional meltdown" occurring in the Great Lakes? Can J Fish Aquat Sci. 2001;58: 2513-25.

4. Blackburn TM, Pyšek P, Bacher S, Carlton JT, Duncan RP, Jarošik V, et al. A proposed unified framework for biological invasions. Trends Ecol Evol. 2011; 26:333-9.

5. Williamson MH, Brown KC, Holdgate MW, Komberg H, Southwood R, Mollison D. The analysis and modeling of British invasions [and discussion]. Philos T Roy Soc B. 1986;314:505-22.

6. Williamson M, Fitter A. The varying success of invaders. Ecology. 1996;77: 1661-6. 
7. Torchin ME, Mitchell CE. Parasites, pathogens, and invasions by plants and animals. Front Ecol Environ. 2004;2:183-90.

8. Prenter J, MacNeil C, Dick JTA, Dunn AM. Roles of parasites in animal invasions. Trends Ecol Evol. 2004:19:386-90.

9. Dunn AM, Torchin ME, Hatcher MJ, Kotanen PK, Blumenthal DM, Byers JE, et al. Indirect effects of parasites in invasions. Funct Ecol. 2012;26:1262-74.

10. Tompkins DM, White AR, Boots M. Ecological replacement of native red squirrels by invasive greys driven by disease. Ecol Lett. 2003;6:189-96.

11. Keane RM, Crawley MJ. Exotic plant invasions and the enemy release hypothesis. Trends Ecol Evol. 2002;17:164-70

12. Torchin ME, Lafferty KD, Dobson AP, McKenzie VJ, Kuris AM. Introduced species and their missing parasites. Nature. 2003;421:628-30.

13. Mitchell CE, Agrawal AA, Bever JD, Gilbert GS, Hufbauer RA, Klironomos JN, et al. Biotic interactions and plant invasions. Ecol Lett. 2006;9:726-40.

14. Sargent LW, Baldridge AK, Vega-Ross M, Towle KM, Lodge DM. A trematode parasite alters growth, feeding behaviour and demographic success of invasive rusty crayfish (Orconectes rusticus). Oecologia. 2014;175:947-58.

15. Strayer DL. Alien species in fresh waters: ecological effects, interactions with other stressors, and prospects for the future. Freshw Biol. 2010;55:152-74

16. Holdich DM, James J, Jackson C, Peay S. The North American signal crayfish with particular reference to its success as an invasive species in Great Britain. Ethol Ecol Evol. 2014;26:232-62.

17. James J, Slater FM, Cable J. A.L.I.E.N. databases: Addressing the Lack In Establishment of Non-natives databases. Crustaceana. 2014;87:1192-9.

18. Kouba A, Petrusek A, Kozák P. Continental-wide distribution of crayfish species in Europe: update and maps. Knowl Manag Aquat Ecosyst. 2014;413:1-31.

19. Kawai T, Mitamura T, Ohtaka A. The taxonomic status of the introduced North American signal crayfish, Pacifastacus leniusculus (Dana, 1852) in Japan, and the source of specimens in the newly reported population in Fukushima prefecture. Crustaceana. 2004;77:861-70.

20. Twardochleb LA, Olden JD, Larson ER. A global meta-analysis of the ecological impacts of nonnative crayfish. Freshw Sci. 2013;32:1367-82.

21. James J, Slater FM, Vaughan IP, Young KA, Cable J. Comparing the ecological impacts of native and invasive crayfish: could native species translocation do more harm than good? Oecologia. 2015;178:309-16.

22. Longshaw M. Diseases of crayfish: a review. J Invertebr Pathol. 2011;106: 54-70.

23. Unestam T, Weiss DW. The host-parasite relationship between freshwater crayfish and the crayfish disease fungus Aphanomyces astaci: response to infection by a susceptible and a resistant species. J Gen Microbiol. 1970;60: 77-90.

24. Holdich DM, Reeve ID. Distribution of freshwater crayfish in the British Isles, with particular reference to crayfish plague, alien introduction and water quality. Aquat Conserv. 1991;1:139-58.

25. Kozubíkova E, Filipová L, Kozák P, Duuriš Z, Martín MP, Dieguez-Uribeondo J, et al. Prevalance of the crayfish plague pathogen Aphanomyces astaci in invasive American crayfishes in the Czech Republic. Conserv Biol. 2009;23: 1204-13.

26. Schrimpf A, Maiwald T, Vrålstad T, Schulz HK, Śmietana O, Schulz R. Absence of the crayfish plague pathogen (Aphanomyces astaci) facilitates coexistence of European and American crayfish in central Europe. Freshw Biol. 2013;58: $1116-25$.

27. Gelder SR. Zoogeography of branchiobdellidans (Annelida) and temnocephalidans (Platyhelminthes) ectosymbiotic on freshwater crustaceans, and their reactions to one another in vitro. Hydrobiologia. 1999; 406:21-31.

28. Franzén $\AA$. Notes on the morphology and histology of Xironogiton instabila (Moore, 1893) (Fam. Branchiobdellidae) with special reference to the muscle cells. Zool Bidr Upps. 1962;35:369-83.

29. Subchev MA. Branchiobdellida (Annelida: Clitellata) found in the crayfish and annelid collections of the French National Museum of Natural History (Paris), and on recently collected crayfishes from France. Acta Zool Bulgar. 2008;60:233-7.

30. Kirjavainen J, Westman K. Natural history and development of the introduced signal crayfish, Pacifastacus leniusculus, in a small, isolated Finnish lake, from 1968 to 1993. Aquat Living Resour. 1999;12:387-401.

31. Oscoz J, Tomás P, Durán C. Review and new records of non-indigenous freshwater invertebrates in the Ebro River basin (Northeast Spain). Aquat Invasions. 2010;5:263-84.

32. Vedia I, Oscoz J, Rueda J, Miranda R, García-Roger EM, Baquero E, et al. An alien ectosymbiotic branchiobdellidan (Annelida: Clitellata) adopting exotic crayfish: a biological co-invasion with unpredictable consequences. Inland Waters. 2014:5:89-92

33. Quaglio F, Fioravanti ML, Gelder SR, Giannetto S, Trentini M, Nobile L, et al. Infestation of the branchiobdellidan, Xironogiton victoriensis (Annelida: Clitellata), on the signal crayfish (Pacifastacus leniusculus) from Auenbachl Creek, Alto Adige/Süd Tyrol, Italy. Freshw Crayfish. 2001;13: 274-9.

34. Oberkofler B, Quaglio F, Fureder L, Fioravanti ML, Giannetto S, Morolli C, et al. Species of Branchiobdellidae (Annelida) on freshwater crayfish in south Tyrol (northern Italy). B Fr Pêche Piscic. 2002;367:777-84.

35. Laurent PJ. A French population of Pacifastacus leniusculus bears the North American parasite branchiobdellidan ecto-symbionts Xironogiton victoriensis. Crayfish News. 2007;29:5-6.

36. Gelder SR, Parpet JF, Quaglio F. First report of two North American branchiobdellidans (Annelida: Clitellata) or crayfish worms on signal crayfish in Europe with a discussion of similar introductions into Japan. Ann Limnol Int J Lim. 2012:48:315-22.

37. Kovács T, Juhász P. Data to the distribution of crayfish worms (Branchiobdellidae) in Hungary. Folia Historica-Naturalia Musei Matraensis. 2007:31:77-9.

38. James J, Cable J, Richardson G, Davidson KE, Mackie ASY. Two alien species of Branchiobdellida (Annelida: Clitellata) new to the British Isles: a morphological and molecular study. Aquat Invasions. 2015;10:371-83.

39. Skelton J, Farrell KJ, Creed RP, Williams BW, Ames C, Helms BS, et al. Servants, scoundrels, and hitchhikers: current understanding of the complex interactions between crayfish and their ectosymbiotic worms (Branchiobdellida). Ontogenetic shift in host tolerance controls initiation of a cleaning symbiosis. Freshw Sci. 2013;32:1345-57.

40. Bishop JE. An ecological study of the Branchiobdellid commensals of some mid western Ontario crayfish. Can J Zool. 1968:46:835-43.

41. Keller TA. The effect of the branchiobdellid annelid Cambarincola fallax on the growth rate and condition of the crayfish Orconectes rusticus. J Freshw Ecol. 1992;7:165-71.

42. Govedich FR, Bain BA, Moser WE, Gelder SR, Davies RW, Brinkhurst RO. In: Thorp $\mathrm{JH}$, Covich AP, editors. Ecology and classification of North American freshwater invertebrates $3^{\text {rd }}$ edition. London UK: Academic Press; 2009. p. 385-410.

43. Brown BL, Creed RP, Dobson WE. Branchiobdellid annelids and their crayfish hosts: are they engaged in a cleaning symbiosis? Oecologia. 2002;132:250-5.

44. Brown BL, Creed RP, Skelton J, Rollins MA, Farrell KJ. The fine line between mutualism and parasitism: complex effects in a cleaning symbiosis demonstrated by multiple field experiments. Oecologia. 2012;170:199-207

45. Lee JH, Won Kim T, Choe JC. Commensalism or mutualism: conditional outcomes in a branchiobdellid-crayfish symbiosis. Oecologia. 2009;159: 217-24

46. Hobbs Jr HH, Holt PC, Walton M. The crayfishes and their epizootic ostracod and branchiobdellid associates of the Mountain Lake, Virginia, region. Proc US Nat Mus. 1967;123:1-84.

47. Rosewarne PJ, Mortimer RJG, Dunn AM. Branchiobdellidan infestation on endangered white clawed crayfish (Austropotamobius pallipes) in the UK. Parasitology. 2012;139:774-80.

48. Ravel A, Kotler BP, Abramsky Z, Krasnov BR. Driven to distraction: detecting the hidden costs of flea parasitism through foraging behaviour in gerbils. Ecol Lett. 2011;14:47-51.

49. Gelder SR, Hall LA. Description of Xironogiton victoriensisn. sp. from British Columbia, Canada, with remarks on other species and a Wagner analysis of Xironogiton (Clitellata: Branchiobdellida). Can J Zool. 1990;68:2352-9.

50. Farrell KJ, Creed RP, Brown BL. Preventing overexploitation in a mutualism: partner regulation in the crayfish-branchiobdellid symbiosis. Oecologia. 2014:174:501-10.

51. R Development Core Team. R: A language and environment for statistical computing. Vienna: R Foundation for Statistical Computing; 2009. http://www.R-project.org. ISBN 3-900051-07-0. Access 12-11-2015.

52. Pinheiro JC, Bates DM. Mixed-effects models in S and S-PLUS. New York: Springer Verlag; 2000.

53. Thomas R, Vaughan I, Lello J. Data analysis with $R$ statistical software: a guidebook for scientists. Cardiff: Eco-explore; 2013.

54. Crawley MJ. Statistical modelling. In: Crawley MJ, editor. The R book England: Wiley; 2007. p. 323-86 
55. Yoder JA, Tank JL, Brown BL, Hobbs III HH. Water exchange pertaining to host attachment sites and stream preference in crayfish-associated branchiobdellids, Cambarincola fallax and Cambarincola ingens (Annelida: Clitellata). Hydrobiologia. 2007;592:523-33.

56. Bovberg RV. Some factors affecting aggressive behavior in crayfish. Physiol Zool. 1956;29:127-36.

57. Young W. Ecological studies of the Branchiobdellidae (Oligochaeta). Ecology. 1966;47:571-8.

58. Corey S. Comparative fecundity of four species of crayfish in Southwestern Ontario, Canada (Decapoda, Astacidea). Crustaceana. 1987;52:276-86.

59. Aquiloni L, Gherardi F. Mutual mate choice in crayfish: large body size is selected by both sexes, virginity by males only. J Zool. 2007;274:1-9.

\section{Submit your next manuscript to BioMed Central} and take full advantage of:

- Convenient online submission

- Thorough peer review

- No space constraints or color figure charges

- Immediate publication on acceptance

- Inclusion in PubMed, CAS, Scopus and Google Scholar

- Research which is freely available for redistribution 